\title{
The influence of calcined mixture cooling method on hydration products composition of blended cement stone
}

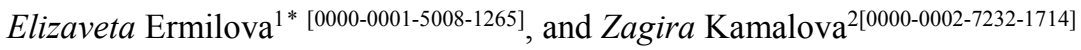 \\ ${ }^{1}$ LLC «Engineering Center of High-Rise Special Technology, 420088, Kazan, Russia \\ ${ }^{2}$ Kazan State University of Architecture and Engineering, 420043, Zelenaya st., Kazan, Russia
}

\begin{abstract}
Complex additives based on combinations of calcined clays, including kaolinite with limestone, due to the synergetic effect play a major role in the creation of blended cements. Usually carbonate rocks contain clay impurities with adverse effects on the properties of the resultant cements and concretes. At the same time calcium carbonate contained in marl clays during calcination allows getting high-quality pozzolanic material. The effective complex additive based on the calcined mixture of clay and limestone was created. The aim of the study is to determine the effect of fast and slow cooling methods of the artificial mixture after calcination on the hydration products composition of blended cement stone with complex additives of calcined mixtures of clays and carbonates. Obtained results allow determining the conditions for obtaining effective complex additives based on calcined mixtures of ubiquitous clays and carbonate rocks for their application in blended Portland cement, and thus to expand the range of the latter. It is found that the preferred method is the fast cooling of the resulting mixture, which contributes to obtaining a complex additive with higher pozzolanic properties, compared with the additive obtained by the slow cooling method.
\end{abstract}

Keywords: blended cement, active mineral additives, calcined mixture, limestone, polymineral clay.

\section{Introduction}

Complex additives differing by the synergetic effect presence in the co-introduction of multiple mineral additives play a major role in the blended cements creation [1-5]. One of the more promising approaches is devoted to the creation of complex additives based on combinations of calcined clays, including kaolinite with limestone [1-3].

Usually carbonate rocks contain clay impurities with adverse effects on the properties of the resultant cements and concretes. At the same time calcium carbonate contained in marl clays during calcination allows getting high quality pozzolanic material.

The main products formed during low-temperature solid-phase synthesis are: onecalcium aluminate, which is formed at a temperature of $500{ }^{\circ} \mathrm{C}[6]$ and dicalcium silicate, which is formed at $700-800{ }^{\circ} \mathrm{C}[6,7]$.

\footnotetext{
* Corresponding author: lizabeta 91@list.ru
} 
At the same time, dicalcium silicate according to N.A. Toropov [8] can exist in five modifications; moreover, three of them are formed only as a result of sintering. For lowtemperature solid-phase synthesis, $\beta \mathrm{C}_{2} \mathrm{~S}$ and $\gamma \mathrm{C}_{2} \mathrm{~S}$ are characteristic. The first one is active, but unstable and, upon slow cooling, is capable of transforming into the second, which is extremely undesirable, due to the fact that $\gamma \mathrm{C} 2 \mathrm{~S}$ does not possess hydraulic properties under normal conditions.

The stability of $\beta \mathrm{C}_{2} \mathrm{~S}$ is determined by both the presence of impurities and the size of the crystals. In the case of impurities, the stabilization of the $\beta \mathrm{C}_{2} \mathrm{~S}$ transition to $\gamma \mathrm{C}_{2} \mathrm{~S}$ is facilitated by the presence of $\mathrm{MgO}, \mathrm{Al}_{2} \mathrm{O}_{3}, \mathrm{Cr}_{2} \mathrm{O}_{3}, \mathrm{~K}_{2} \mathrm{O}, \mathrm{Na}_{2} \mathrm{O}, \mathrm{Fe}_{2} \mathrm{O}_{3}, \mathrm{P}_{2} \mathrm{O}_{5}, \mathrm{SO}_{3}$, due to the fact that metal ions can replace calcium ions, and the $\left[\mathrm{SiO}_{4}\right]^{4-}$ group can replace $\left[\mathrm{SO}_{4}\right]^{2-}$ and $\left[\mathrm{PO}_{4}\right]^{3-}[9-11]$. At the same time, the stability of crystals increases with a decrease in their size [12].

As applied to the production of Portland cement clinker, the method of quenching is used to stabilize $\beta C_{2} S$, while the glassy phase covers the $\beta C_{2} S$ grains, preventing their expansion.

The aim of the work was to determine the effect of fast and slow methods of cooling an artificial mixture after thermal activation on the composition of hydration products of a composite cement stone with complex additives of thermally activated mixtures of clays and carbonates.

\section{Experimental}

\subsection{Materials and characteristic}

All experiments were carried out using the OPC CEM I 42,5 N according EN 197-1 $\left(\mathrm{C}_{3} \mathrm{~S}-\right.$ 68,$\left.0 ; \mathrm{C}_{2} \mathrm{~S}-10,0 ; \mathrm{C}_{3} \mathrm{~A}-3.7 ; \mathrm{C}_{4} \mathrm{AF}-15\right)$. As polymineral clays selected were the kaolinitic clay with chemical composition, mass \%: CaO-0,20; $\mathrm{SiO}_{2}-69,18 ; \mathrm{Al}_{2} \mathrm{O}_{3}-19,55 ; \mathrm{Fe}_{2} \mathrm{O}_{3}-1,32$; $\mathrm{MgO}-0,42 ; \mathrm{SO}_{3}-<0,05 ; \mathrm{Na}_{2} \mathrm{O}-<0,3 ; \mathrm{K}_{2} \mathrm{O}-0,92 ; \mathrm{TiO}_{2}-1,36 ; \mathrm{MnO}-0,01 ; \mathrm{P}_{2} \mathrm{O}_{5}-<0,3$, and the polymineral clay with chemical composition, mass \%: CaO-2,16; $\mathrm{SiO}_{2}-64,5 ; \mathrm{Al}_{2} \mathrm{O}_{3}-13,96$; $\mathrm{Fe}_{2} \mathrm{O}_{3}-7,30 ; \mathrm{MgO}-2,18 ; \mathrm{FeO}-0,88 ; \mathrm{SO}_{3}-<0,05 ; \mathrm{Na}_{2} \mathrm{O}-0,98 ; \mathrm{K}_{2} \mathrm{O}-1,97 ; \mathrm{TiO}_{2}-1,97 ; \mathrm{MnO}-$ 0,$10 ; \mathrm{P}_{2} \mathrm{O}_{5}-0,11$. The specific surface is $500 \mathrm{~m}^{2} / \mathrm{kg}$. As carbonate rocks were adopted two limestones L1 and L2.

The mineral compositions of materials are presented in Table 1. The differential thermal curves of clays are shown in Fig. 1, 2.

The specific surface is $500 \mathrm{~m}^{2} / \mathrm{kg}$.

Table 1. Mineral compositions of clays.

\begin{tabular}{|c|c|c|c|c|}
\hline $\begin{array}{c}\text { Mineral } \\
\text { composition (\%) }\end{array}$ & $\begin{array}{c}\text { Kaolinitic clay } \\
(\mathrm{KC})\end{array}$ & $\begin{array}{c}\text { Polymineral clay } \\
(\mathrm{PC})\end{array}$ & Limestone (L1) & Limestone (L2) \\
\hline Kaolinite & 82.3 & 4.06 & - & - \\
\hline Quartz & 17.7 & 35.8 & 1 & 5.33 \\
\hline Calcite & - & - & 99 & 87.37 \\
\hline Albite & & 14.79 & & 1.19 \\
\hline Montmorillonite & & 17.9 & & 6.11 \\
\hline Muscovite & & & & \\
\hline Microcline & & 17.4 & & \\
\hline Chloride & & 4.1 & & \\
\hline Mica & & 6.0 & & \\
\hline
\end{tabular}




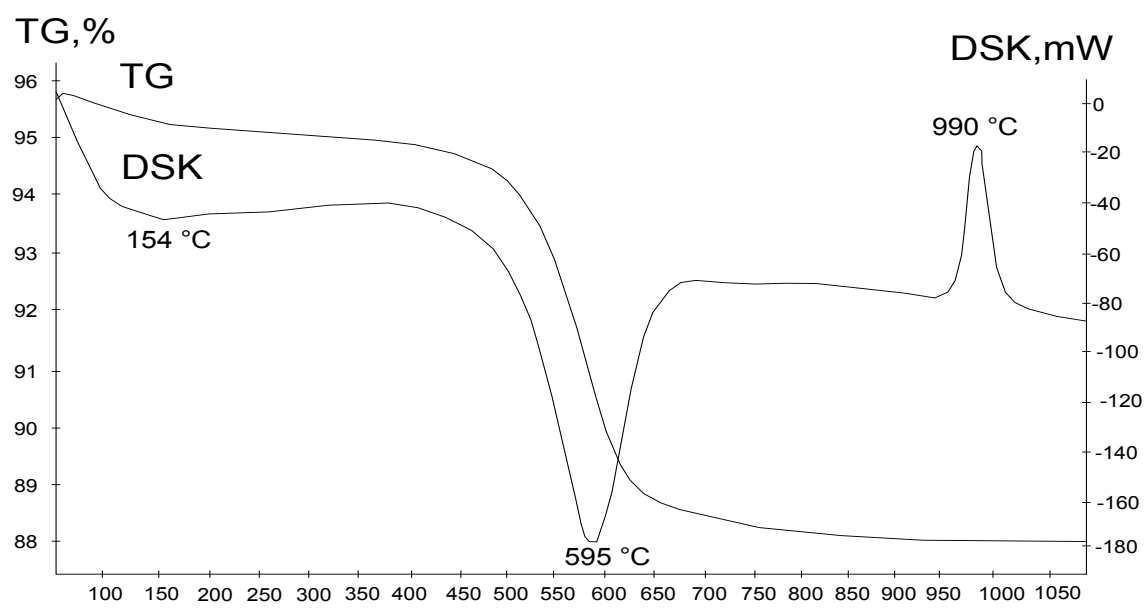

Fig. 1. Simultaneous TG-DTA data of kaolinitic clay.

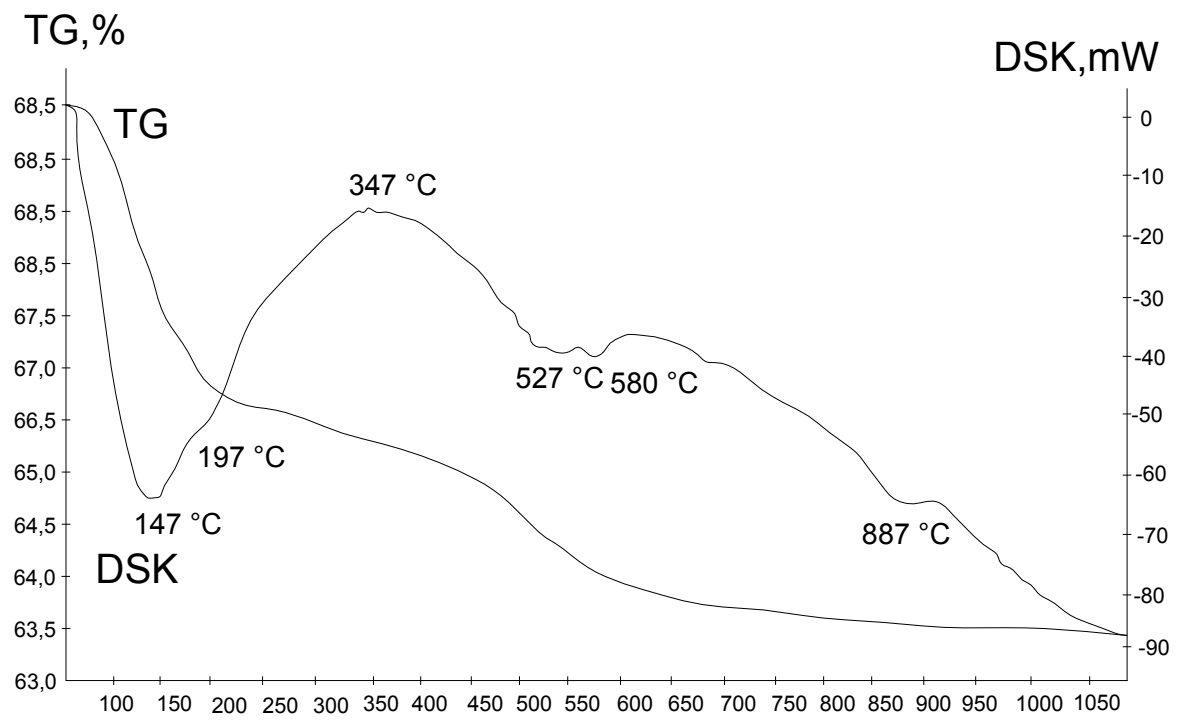

Fig. 1. Simultaneous TG-DTA data of polimineral clay.

\subsection{Methodology}

The calcination of mixture was conducted in the laboratory chamber furnace SNOL $7.2 / 1100$ with a vacuum fiber chamber.

Calcined mixtures were introduced into the OPC in amount of $20 \%$ of its mass according to the GOST 31108-2016 and the EN 197-1:2000.

The thermal analysis of blended cement stone was carried out using a combined method of thermogravimetry (TG) and differential scanning calorimetry (DSC) when using thermoanalyzer NETZSCH STA 449C under continuous heating $\left(40\right.$ to $\left.1000^{\circ} \mathrm{C}\right)$ samples with a mass of about $35-40 \mathrm{mg}$ at a rate of $10{ }^{\circ} \mathrm{C} / \mathrm{min}$ in a flow $(50 \mathrm{ml} / \mathrm{min})$ of air in alund 
crucibles. Temperatures of thermal effects are determined with an accuracy of $\pm 1-3{ }^{\circ} \mathrm{C}$, warmth $- \pm 5 \%$, weight of $\pm 0.01 \mathrm{mg}$.

\section{Results and discussion}

The complex additive was introduced in an amount $20 \%$ by Portland cement weight. The specific surface of mixtures was $500 \mathrm{~m}^{2} / \mathrm{kg}$.

The following compositions of calcined mixtures of clays and limestones were selected for research:

1. Kaolinitic clay and limestone L1;

2. Polymineral clay and limestone L2.

The choice of the compositions of mixtures is due to the results of previous studies, presented in printed works [13-16].

\subsection{Hydration products composition of blended cements with the complex additive}

The research of hydration products composition was conducted on cement stone samples at the 28 days age with following compositions:

1. The control sample of OPC;

2. The blended cement with $20 \%$ of complex additive based on calcined mixture of kaolinitic clay and limestone L1;

3. The blended cement with $20 \%$ of complex additive based on calcined mixture of polimineral clay and limestone L2;

In Fig. 3 simultaneous TG-DTA of control sample OPC cement stone is submitted. The observed endothermic effect with the maximum at $70{ }^{\circ} \mathrm{C}$ can be bound with loss of free water from a cement stone [17]. The nearby endothermic effect at a temperature of 100-125 ${ }^{\circ} \mathrm{C}$ is associated with the release of adsorption water from calcium hydrosilicates $(\mathrm{CaO}$. $\mathrm{SiO}_{2} \cdot 2 \mathrm{H}_{2} \mathrm{O}$ ) [17]. The endothermic effect in the temperature range of $125-150{ }^{\circ} \mathrm{C}$ is characteristic of dehydration of calcium hydrosilicates of the types $2 \mathrm{CaO} \cdot 3 \mathrm{SiO}_{2} \cdot 2 \mathrm{H}_{2} \mathrm{O}$ and $5 \mathrm{CaO} \cdot 6 \mathrm{SiO}_{2} \cdot 9 \mathrm{H}_{2} \mathrm{O}$ and ettringite [18-20]. The calcium hydroxide present in the sample decomposes with an endothermic effect at a temperature maximum of $460.65{ }^{\circ} \mathrm{C}$ [18].

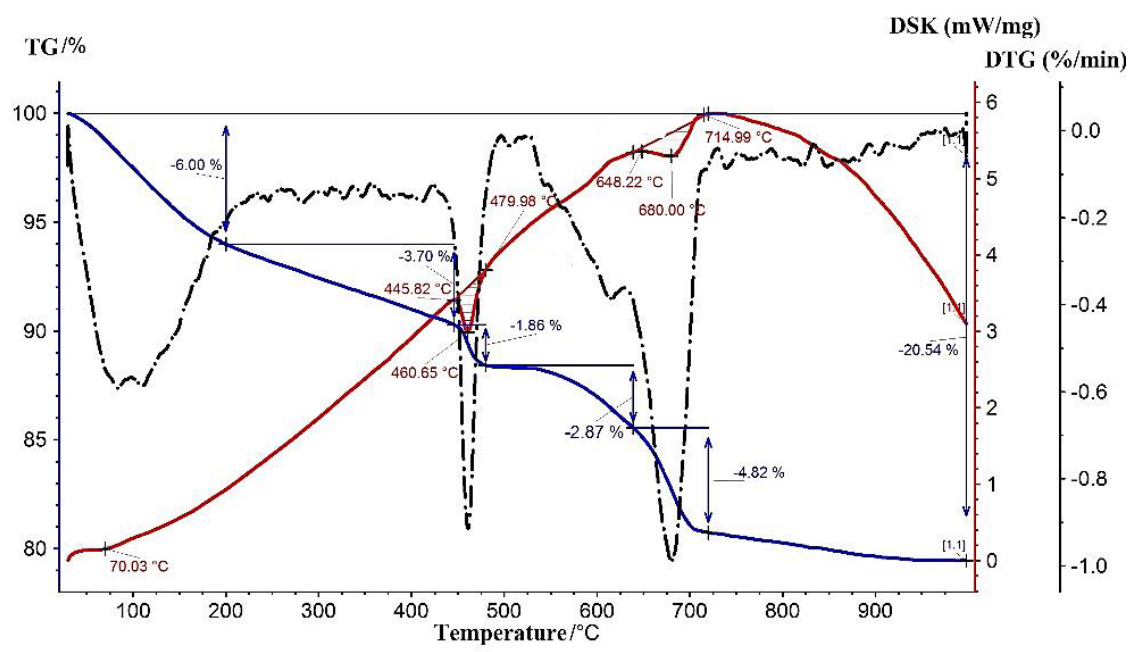

Fig. 3. Simultaneous TG-DTA-DSC data of control OPC cement stone sample. 
On the simultaneous TG-DTA data of the mixture sample obtained by rapid cooling (Fig. $4 \mathrm{~b}$ ), at temperatures of $480.0-668.72{ }^{\circ} \mathrm{C}$, a decrease in the mass of the sample is observed. At the same time, at temperatures of $668.72-708.04{ }^{\circ} \mathrm{C}$, the decomposition of low-basic calcium hydrosilicates the C-S-H (I) type formed in the hydration process occurs [18]. Decomposition of highly basic hydrosilicates and metastable products of their carbonization is characterized by an endothermic effect at $708.04{ }^{\circ} \mathrm{C}$, similar to the sample without additives. Limestone calcium carbonate, which has not entered into the thermal synthesis reaction, decomposes at a temperature of $733.4{ }^{\circ} \mathrm{C}$.

As can be seen from Fig. 4 for the sample with the additive of slow cooling, a clearly pronounced endothermic effect at $745.0{ }^{\circ} \mathrm{C}$ indicates, first of all, the decomposition of thermally unreacted relict calcium carbonate of limestone, as well as the dehydration of highly basic hydrosilicates and metastable products of their carbonization. At the same time, the weight loss, amounting to $7.23 \%$, is greater than for sample with additive of a rapid cooling mixture. Based on this, it can be concluded that compounds of the CS and CSA types are more actively formed during the mixtures calcination of polymineral clays and carbonate rocks obtained by rapid cooling.

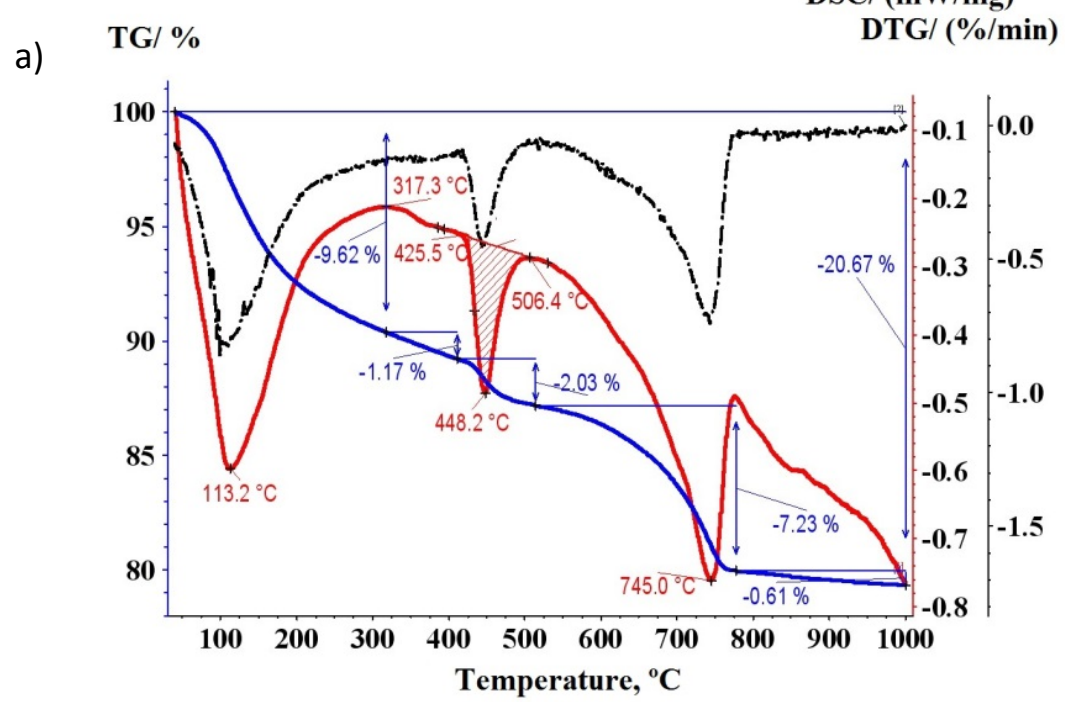

$$
\begin{aligned}
& \mathrm{DSC} /(\mathrm{mW} / \mathrm{mg}) \\
& \text { DTG/ }(\% / \mathrm{min})
\end{aligned}
$$

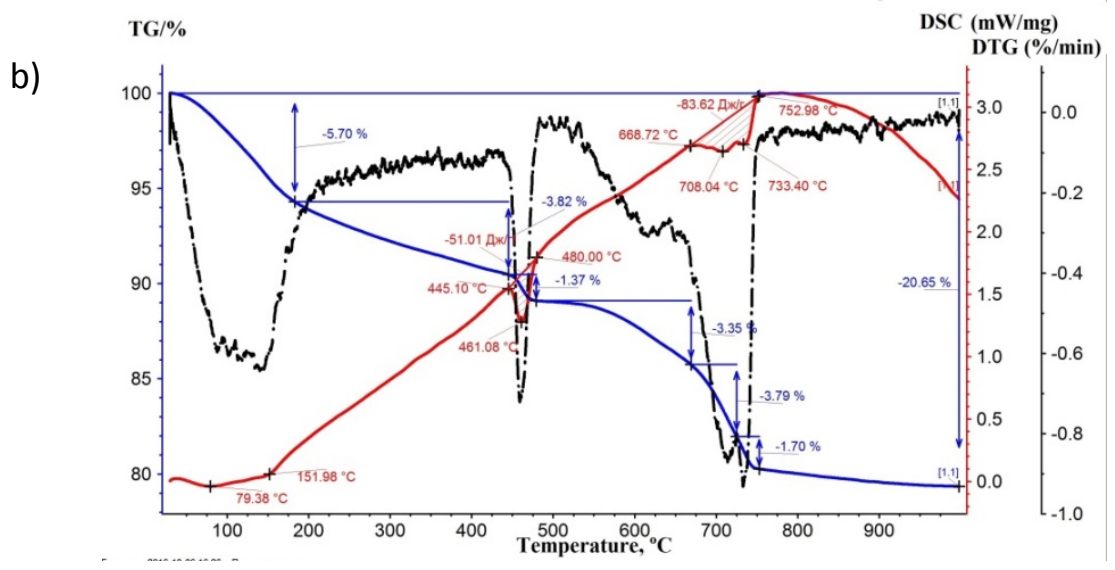

Fig. 4. Simultaneous TG-DTA-DSC data of blended cement stone sample with $20 \%$ of complex additive based on calcined mixture of kaolinitic clay and limestone L1: a) with slow cooling; b) with rapid cooling. 
Small exothermic effects at $850^{\circ} \mathrm{C}$, typical for the vollastonite formation from calcium hydrosilicates [18], are observed for both methods of mixture cooling.

Simultaneous TG-DTA data of cement stone with the second type of additive are shown in Fig. 5, with a slow (a) and fast (b) cooling method, respectively.

For the mixture of slow cooling (Fig. 5a) the endothermic effect at $108.7{ }^{\circ} \mathrm{C}$ characterizes the loss of adsorption water from hydrosilicates and ettringite. With rapid cooling, the endothermic effect of free water loss is observed at a temperature maximum at $73.02{ }^{\circ} \mathrm{C}$, similar to the control composition. Dehydration of low-basic hydrosilicates of the $\mathrm{C}-\mathrm{S}-\mathrm{H}$ (I) type is observed at temperatures of $100-125{ }^{\circ} \mathrm{C}$. Endothermic effects at temperatures of $125-200{ }^{\circ} \mathrm{C}$ are associated with the dehydration of ettringite and calcium hydrocarboaluminates.

a)

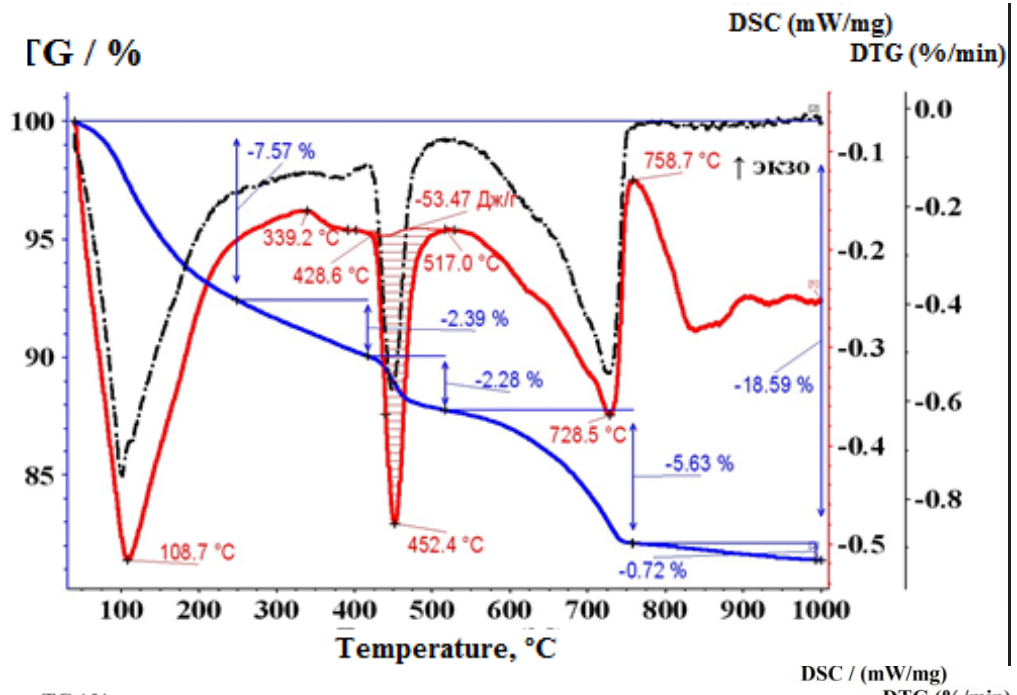

b)

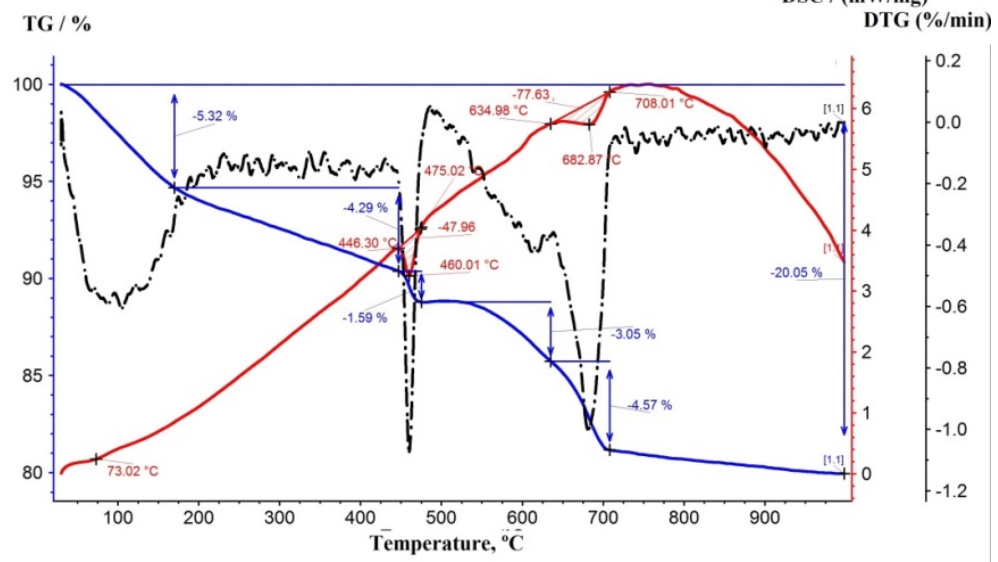

Fig. 5. Simultaneous TG-DTA-DSC data of blended cement stone sample with $20 \%$ of complex additive based on calcined mixture of polimineral clay and limestone L2: a) with slow cooling; b) with rapid cooling.

The calcium hydroxide decomposition for samples with additives of fast and slow cooling corresponds to temperature maxima of 460.01 and $452{ }^{\circ} \mathrm{C}$, respectively. The weight loss associated with the decomposition of calcium hydroxide for the slow cooling sample is 
higher than for the rapid cooling sample, therefore, more of it is formed in this case. The latter indicates a high pozzolanic activity of the rapid cooling additive.

Weak endothermic effects (Fig. 5b) in the temperature range $475.02-634.98{ }^{\circ} \mathrm{C}$ characterize the dehydration of low-basic calcium hydrosilicates of the types C-S-H (A) and C-S-H (B) [17].

The calcium carbonate present in the compositions decomposes with an endothermic effect at a temperature maximum of $682.87^{\circ} \mathrm{C}$ - in the sample with the rapid cooling additive, but in the sample of slow cooling at $728.5^{\circ} \mathrm{C}$. In the first case the decomposition of relict calcium carbonate occurs. In the second case calcium carbonate formed during the samples hydration is similar to the control composition.

Weak exothermic and endothermic effects after 758 and $708{ }^{\circ} \mathrm{C}$ characterize the transition of tobermorite like compounds to vollastonite, as well as the dehydration of hydrosilicates and hydroaluminates of the $\mathrm{C}_{2} \mathrm{SH}_{2}$ and $\mathrm{C}_{4} \mathrm{~A}_{3} \mathrm{H}_{3}$ type [16].

\section{Conclusions}

Using the method of differential scanning calorimetry, it was found that the most effective method is the rapid cooling of artificial mixture of clays and limestones to obtain a complex additive for blended Portland cement.

It has been shown that the use of the rapid cooling method for complex additives makes it possible to obtain a material with higher pozzolanic properties than the slow cooling method, due to the fact that the rapid cooling method is more conducive to the calcium hydroxide binding by the active centers of the obtained complex additive, in comparison with slow cooling method.

A decrease or complete absence of the reaction peak of endothermic relict calcium carbonate decomposition of limestone in a mixture with rapid cooling is established, which suggests that it completely enters into the reaction of solid-phase synthesis in a mixture with rapid cooling.

\section{References}

1. J. Ston, K. Scrivener, Basic creep of limestone-calcined clay cements: An experimental and numerical approach, Theoretical and Applied Fracture Mechanics, 103 (2019) DOI:10.1016/j.tafmec.2019.102270

2. C. Ouellet-Plamondona, S. Scherbb, M. Köberlb, K.-C. Thienelb, Acceleration of cement blended with calcined clays, Construction and Building Materials, 245 (2020) DOI: 10.1016/j.conbuildmat.2020.118439

3. Z. Shia, S. Ferreirob, B. Lothenbach, R. Rica, G. Wolfgang, K. Josef, K. Duncan, H.G. Skibsteda, Sulfate resistance of calcined clay - Limestone - Portland cements, Cem. and Conc. Res., 116, 238-251 (2019) DOI:10.1016/j.cemconres.2018.11.003

4. K. Krishnana, S. K. Kanaujiaa, S. Mithiab, S. Bishnoia, Hydration kinetics and mechanisms of carbonates from stone wastes in ternary blends with calcined clay, Construction and Building Materials, 164, 265-274 DOI:1 0.1016/j.conbuildmat.2017.12.240

5. R. Mukhametrakhimov, A. Galautdinov, R. Gilmanshin, Modified gypsum-cementpozzolanic composites rein-forced with polypropylene fibers, IOP Conf. Ser. Mater. Sci. Eng.,570, 012068 (2019) DOI: 10.1088/1757-899X/570/1/012068.

6. V. I. Aksenov. Glinit-cement (Moscow-Leningrad: Russia, General edition of construction literature, 1935) 
7. R. Z. Rakhimov, Z. A. Kamalova, E. Yu.Yermilova, Blended Portland Cement Based on Thermally Activated Clays and Carbonate Additives, Inorganic materials: applied research, 9 (4), 578-583 (2018)

8. N. N. Toropov, N. F. Fedorov, About binding properties of various modifications of the two-calcium silicate, Zhurnal prikladnoi khimii, 12, 2585-2588 (1962)

9. M. K. Young, H. H. Seong, Influence of minor ions on the stability and hydration rate of $\beta$-dicalcium silicate, Journal of American Ceramic Society, 87, 900-905 (2004)

10. S. Sychugov, Y. Tokarev, T. Plekhanova, O. Mikhailova, I. Pudov, R. Faizullin, A. Gaifullin, R. Sagdiev Proc. of the 12th International conference modern building materials, structures and techniques, MBMST 2016, Vilnius, 982-990 (2016)

11. A. Zezulová, T. Staněk, T. Opravil, Influence of barium oxide additions on Portland clinker, Ceramics-Silikáty, 61, 20-25 (2017) DOI: 10.13168/cs.2016.0055.

12. A. A. Pashchenko, Theory of the cement (Kiev.: Budivelnik, 1991)

13. E. Yu. Ermilova, Z. A. Kamalova, R. Z. Rakhimov, O. V. Stoyanov, A. G. Khantemirov, D. A. Gabbasov, R. R. Akhtareev, Study of the influence of rate of the temperature rise at the clay calcination on its pozzolanic activity, Repair. Recovery. Modernization, 4, 25-27 (2017)

14. E. U. Ermilova, R. Z. Rakhimov, Z. A. Kamalova, P. E. Bulanov, Calcined mixture of clay and limestone as a complex additive for blended Portland cement, Zement - Kalk - Gips International, 10, 64-73 (2018)

15. E. Yu. Ermilova, P. E. Bulanov, R. Z. Rakhimov, Z. A. Kamalova, The research the influence of calcined mixtures on the properties of blended cement, Izvestiya KGASU, 2, 220-227 (2017)

16. E. Ermilova, Z. Kamalova, R. Z. Rakhimov, Influence of Clay Mineral Composition on Properties of Blended Portland cement with Complex Additives of Clays and Carbonates, in Proc. 1st International Scientific Conference on Sociotechnical Construction and Civil Engineering, STCCE-2020, April 2020, Kazan, Russia (2020)

17. E. U. Ermilova, P. E. Bulanov, R. Z. Rakhimov, O. V. Stoyanov, Blended Portland cement with complex additive based on the mineral raw materials of the Tatarstan Republic, Vestnik Kazanskogo tekhnologicheskogo universiteta, 8, 36-40 (2018)

18. I. A. Makarova, N. Lokhova, Physico-chemical methods for research of construction materials: training manual (Bratsk: Publisher Bratsk state University, 2011)

19. Proc. $14^{\text {th }}$ International Congress on the Chemistry of cement, 13-16 October 2015, Beijing, China I (2015)

20. Proc. $15^{\text {th }}$ International Congress on the Chemistry of cement, 16-20 September 2019, Prague, Czech Republic I (2019) 